Apidologie, 1984, 15 (2), 123-136

\title{
EXPLOITATION OF COMB CELLS FOR BROOD REARING IN HONEYBEE COLONIES WITH LARVAE OF DIFFERENT SURVIVAL RATES
}

\author{
Jerzy WOYKE \\ Department of Bee Culture, Agricultural University \\ 02-766 Warszawa, Nowoursynowska 166
}

\begin{abstract}
SUMMARY
Selected genetically known virgin queens were instrumentally inseminated with semen of two of their brothers. This resulted in three groups of queens producing brood of $100 \%, 75 \%$ and $50 \%$ survival rate. The content of 210,780 cells was investigated within the brood area on both sides of every brood comb during two years in 3 hives.

The average content of cells within the brood area of normal colonies was $14 \%$ eggs, $21 \%$ larvae, $51 \%$ sealed brood, $9 \%$ empty cells and $5 \%$ of cells filled with pollen and honey. The proportions varied in different periods and between colonies with different brood survival rates.

In summer, there was a greater percentage of cells containing eggs in colonies with brood of decreased survival rates, and a lower percentage of containing larvae. In autumn, similar percentages of cells with eggs and larvae were found in all three groups of colonies. This indicates a high percentage of larvae being eaten by workers in normal colonies, at the end of the season. In summer, $15 \%, 20 \%$ and $30 \%$ of cells were not used for brood rearing in colonies with $100 \%, 75 \%$ and $50 \%$ of brood survival respectively. There was a lower fraction of cells not used for brood rearing in colonies with decreased percentage survival of larvae, than the fraction of diploid drone larvae eaten by the workers. This indicates, that the queens did not stop egg laying until all the bees had emerged from the comb. They deposited new eggs into empty cells shortly after diploid drone larvae were eaten.
\end{abstract}

When compared to normal colonies less sealed brood was present in colonies with decreased larval survival rate. As a result, colonies with brood of lower survival rate were less populous than the normal ones.

\section{INTRODUCTION}

A series of multiple sex alleles exists in the honeybee (MACKENSEN, 1951). Heterozygosity at this locus in eggs, results in development of females, and 
homozygosity - in diploid drones (Woyke, 1963 a). Diploid drone larvae are eaten by the workers shortly after hatching from the eggs (WOYKE, $1963 \mathrm{~b}$ ).

Depending upon sex alleles of the queen and drones mated to her, 0-50\% of hatching larvae may be eaten by workers. Of course great losses occur to the colony when worker bees do not develop from $50 \%$ of fertilized eggs.

The common belief is that the brood is compact in colonies with $100 \%$ larval survival and is scattered, with $25 \%$ and $50 \%$ of empty cells, in colonies producing larvae of $75 \%$ and $50 \%$ survival respectively. But WoYKe (1980, 1981) showed that interaction exists between brood area, population of bee colonies, and progress of the season. The differences in brood production and bee population, between colonies with larvae of different survival rates, were low in the spring and autumn, when egg laying activity of the queens was low. Differences were higher in the summer, when the queens laid more eggs.

Therefore, exploitation of comb cells for brood rearing probably also differs in colonies with larvae of different survival rates. Whether or not this is true has important theoretical and practical implications, because methods of honeybee breeding in closed populations are now being used (PAGE and LaIDLAW, 1982). Bee breeders using closed population, accept in advance certain levels of decreased brood survival due to homozygosity of sex alleles.

The purpose of this paper is to report results of a study of exploitation of comb cells for brood rearing in colonies producing brood of different survival rates.

\section{MATERIALS AND METHODS}

\footnotetext{
Virgin hybrid Caucasian/Carniolan queens were instrumentally inseminated with the semen of two of their brothers This resulted in three groups of queens producing brood of $100 \%, 75 \%$ and $50 \%$ survival rate. This was achieved through selected combinations of sex alleles ab $\times \mathrm{c}$ which produced ac and $\mathrm{bc}$ virgins and $a$ and $b$ drones.

After virgin queens ac were mated to two of their brothers, the following combinations of sex alleles occurred : $\mathrm{ac} \times \mathrm{a}, \mathrm{a} ; \mathrm{ac} \times \mathrm{a}, \mathrm{b}$ and $\mathrm{ac} \times \mathrm{b}, \mathrm{b}$. Those queens produced $50 \%, 25 \%$ and $0 \%$ of homozygous fertilized eggs, from which diploid drone larvae hatched, and were eaten by the workers. Similar combinations of sex alleles occurred when $b c$ queens were mated to two brothers. Survival rate of brood was investigated by the method described by WoYke (1980). To detect the exploitation of comb cells for brood rearing, the content of cells was investigated in $1 \mathrm{dm}^{2}$ within the centrum of brood area. The cell content was determined on both sides of every brood comb. Investigations were conducted in the spring, summer and autumn during two years. Three colonies of each of the three survival groups were investigated the first year and two to four the second year. In total, the content of 210,780 individual cells was determined.
} 


\section{RESULTS}

\section{Exploitation of comb cells for brood rearing in different periods of the season}

Photographs of three combs with brood survival rates of $100 \%, 75 \%$ and $50 \%$ are presented in Fig. 1. Data concerning particular years (Table 1, 1979 and Table 2, 1980) as well as averages for both years (Table 3) show, that about 3000 fewer brood cells were found in the spring, in colonies producing brood of $50 \%$ survival than in the normal ones. Lower (Table 1) or similar (Table 2) numbers to those in normal colonies were found in the $75 \%$ survival group. The percentage of cells containing eggs was only 2-3\% lower and larvae occupied $11 \%$ fewer cells in colonies of the $50 \%$ survival group than in the normal ones. The percentage of cells with larvae in the $75 \%$ survival group was intermediate.

In normal colonies larvae were found in about 1.6 times $(30.5 \%)$ more cells than the eggs (19.5). This indicates an increase of egg laying rate in subsequent days or eating of part of larvae. Since eggs develop in 3 days and larvae in 6 days, twice as many larvae should be found in the colonies when egg laying was constant and no larvae eaten. But larvae in colonies producing brood of $50 \%$ survival occupied similar percentages of cells as eggs (19.5\% and $17 \%$ respectively). Thus the phenomenon of eating larvae homozygous at sex locus is clearly demonstrated here.

Only $3 \%$ lower percentage of cells with sealed brood was found in colonies producing brood of $50 \%$ survival, than that found in normal colonies.

Percentage of empty cells found within the brood area in colonies of the three groups varied in both years. But the average shows that $7 \%, 10 \%$ and $20 \%$ of empty cells were found among brood of colonies producing larvae of $100 \%$, $75 \%$ and $50 \%$ survival rates, respectively. The total percentage of empty cells within brood area of both groups of colonies with decreased brood survival was much lower than the $25 \%$ and $50 \%$ of diploid drone larvae being eaten by worker bees. This shows that the queens did not wait until all adults emerged from a comb, but lay new eggs into empty cells shortly after diploid drone larvae were eaten from them.

Cells filled with pollen and honey were also found within brood area. The percentage varied in both years and between the three groups of colonies (Tables 1 and 2). Table 3 shows, that the highest percentage of cells with pollen and honey was found in colonies producing larvae of the lowest survival rate. This indicates, that higher percentage of empty cells within the brood area induced workers to put pollen and honey there. 

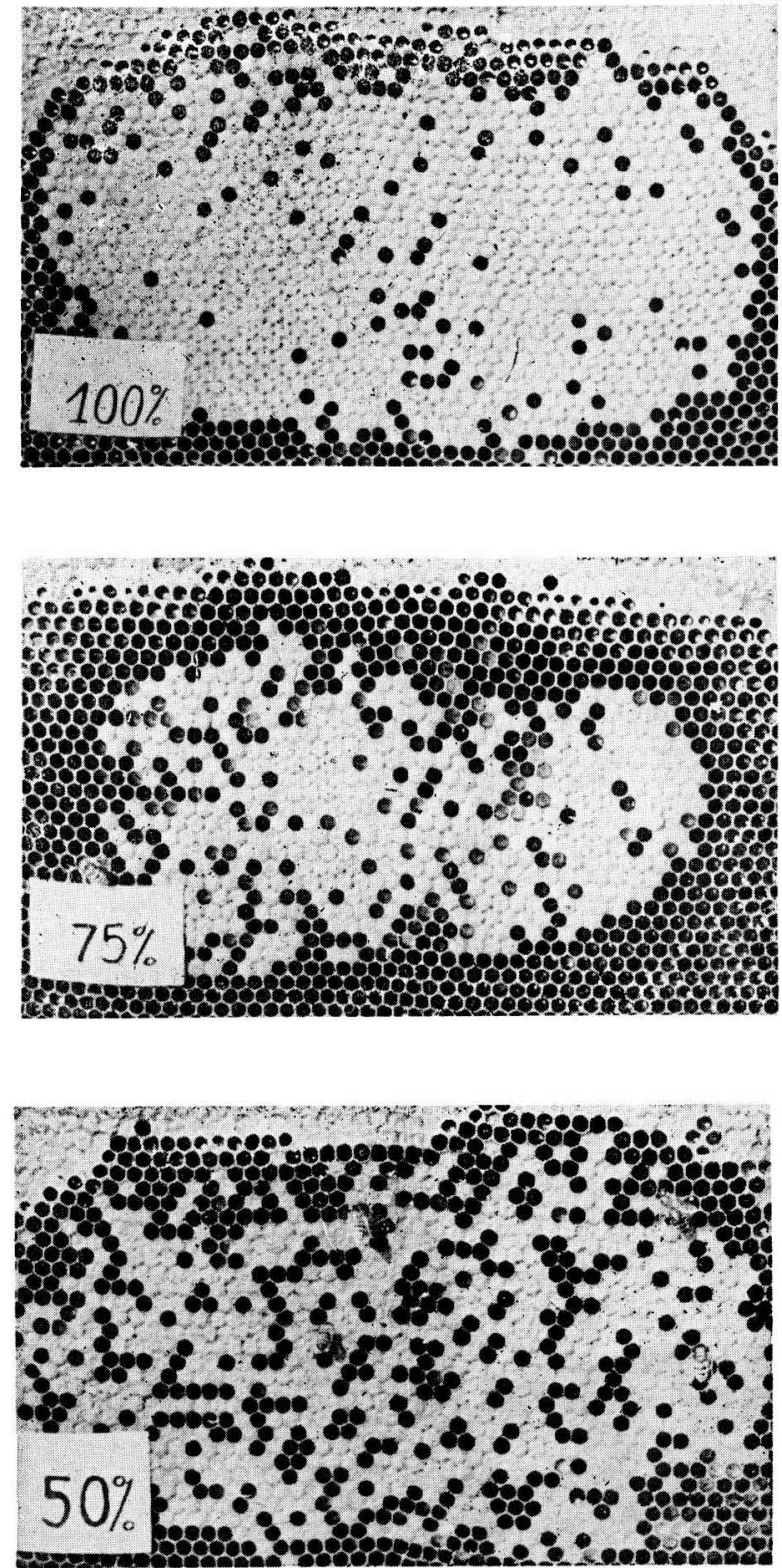

Fig. 1. - Three combs with brood surviving in $100 \%, 75 \%$ and $50 \%$ 


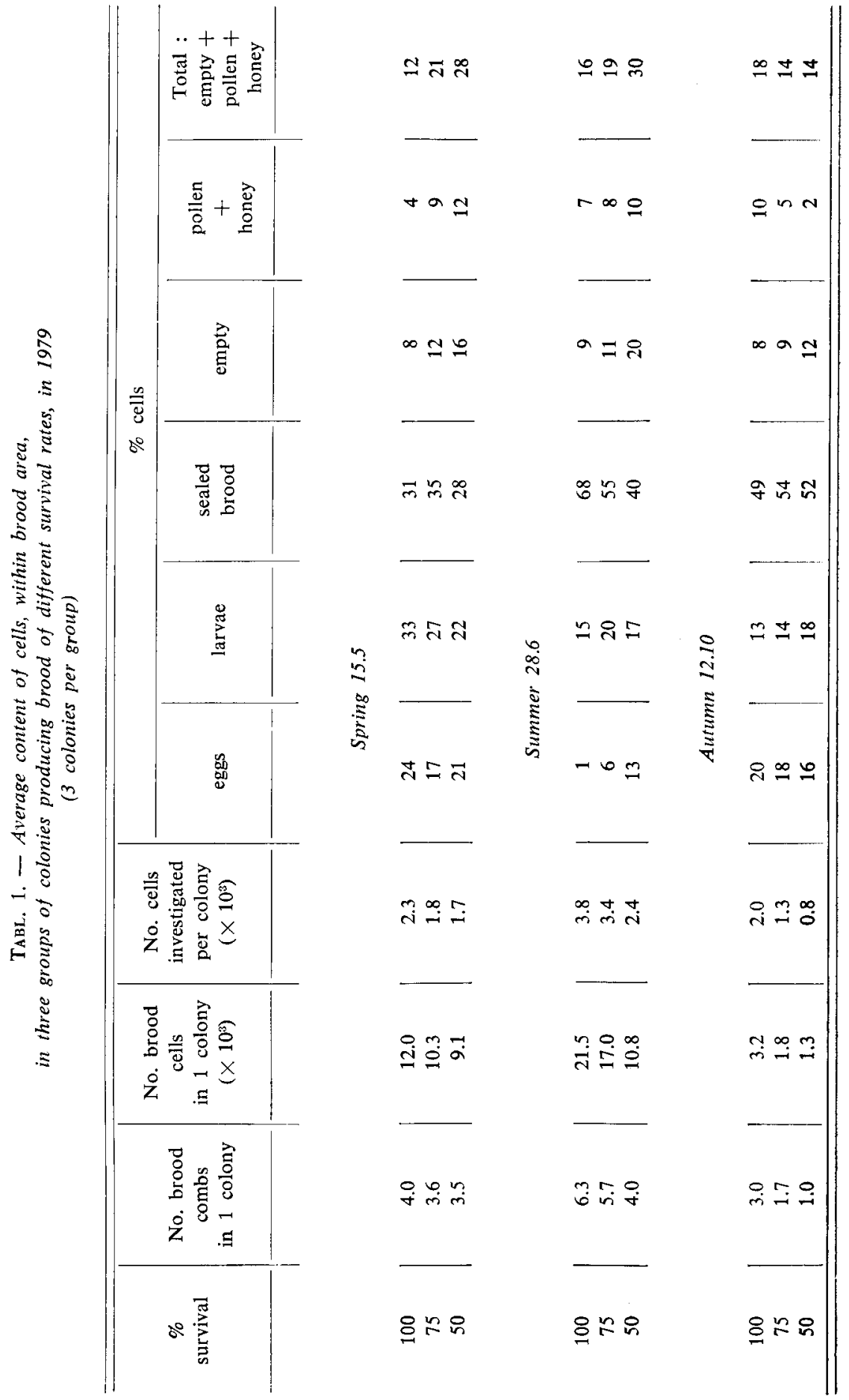




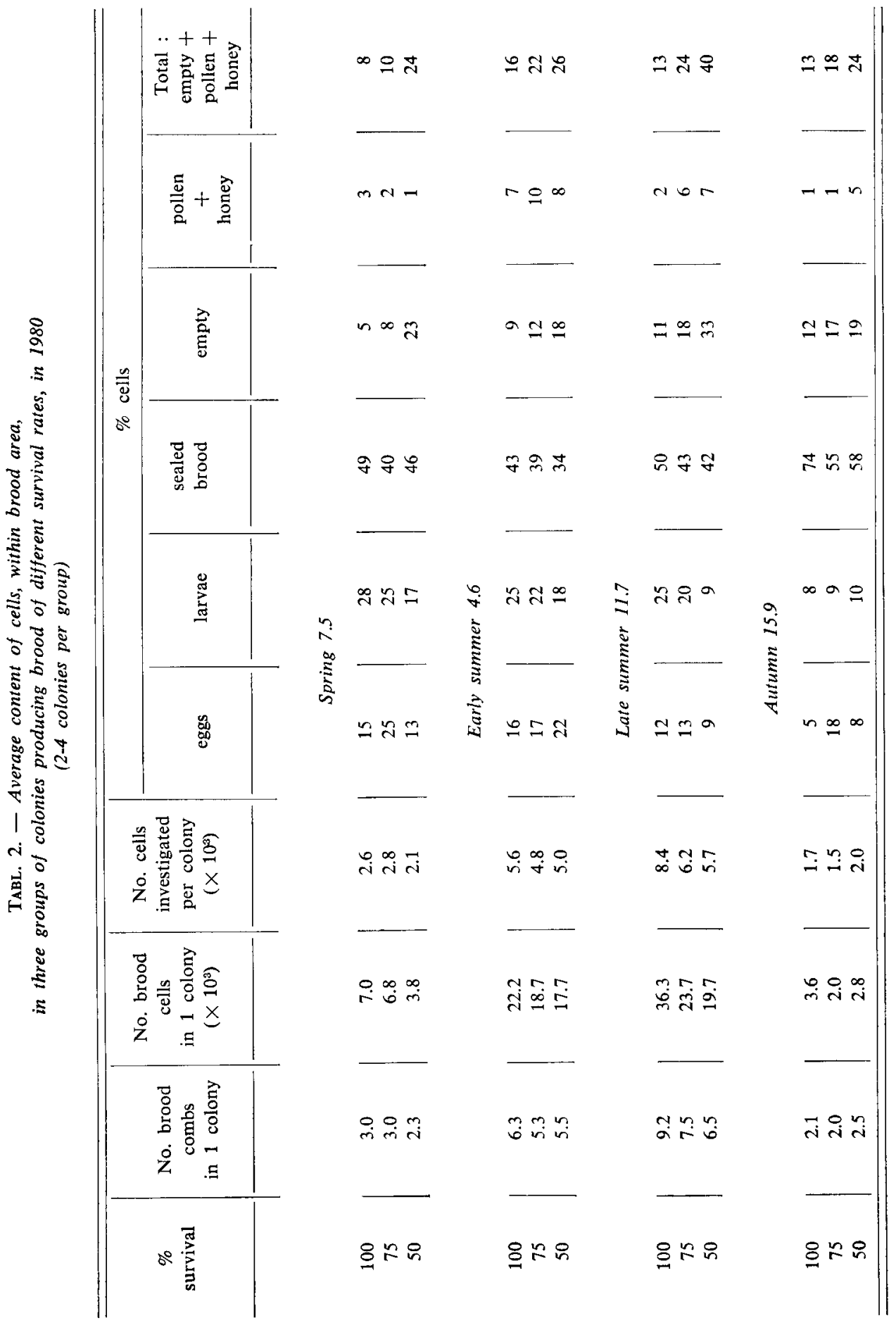


Roughly $10 \%, 15 \%$ and $25 \%$ of cells within brood area were not used in the spring for brood rearing in colonies producing brood of $100 \%, 75 \%$ and $50 \%$ survival, respectively. Even the highest percentage of cells excluded from brood rearing was lower, than the $50 \%$ of larvae being eaten up.

In summer, the number of brood cells increased considerably. The difference between number of brood cells found in normal colonies and in those producing brood of $50 \%$ survival increased from 4.5 thousand in early summer (Table 2) to 10.7 thousand in mid summer (Table 1) and to 16.6 thousand in late summer (Table 3). Percentage of cells with eggs was in early (Table 2) and mid summer (Table 1) higher in colonies of the $50 \%$ survival group than in the normal ones. On average, $5 \%$ more cells with eggs were found in colonies with brood of $50 \%$ survival than in the normal ones. Percentage of cells with larvae and sealed brood was almost always lower in summer in both groups of colonies with decreased brood survival. On average, $7 \%$ fewer cells with larvae and $15 \%$ fewer cells with sealed brood were found in summer in colonies producing larvae of $50 \%$ survival than in the normal ones.

The percentage of empty cells rose in late summer to $11 \%, 18 \%$ and $33 \%$ in colonies producing brood of $100 \%, 75 \%$ and $50 \%$ survival rate (Table 2). Together with cells containing pollen and honey, the percentage of cells excluded from brood rearing rose to $13 \%, 24 \%$ and $40 \%$, respectively. Thus the amount of cells not used for brood rearing approached, in the period of maximal brood production, the $25 \%$ and $50 \%$ of diploid drone larvae being eaten up by workers. On average, about $15 \%, 20 \%$ and $30 \%$ of cells were not used for brood rearing, respectively (Table 3 ).

In autumn, similar or lower percentages of larvae than eggs were found in each of the three groups of colonies. Since the development time of larvae is twice that of eggs, 1.5 to 2 times more larvae should be found in colonies with brood of $100 \%$ or $75 \%$ survival, respectively, if no larvae were eaten. Similar or lower percentages of larvae were found in colonies of the $75 \%$ or $100 \%$ survival than in the $50 \%$ survival one. This indicates that in autumn workers in both groups of colonies with increased brood survival eat similar or higher percentage of larvae than workers in colonies producing $50 \%$ diploid drones. The difference in average percentages of sealed brood cells between colonies with larvae of $50 \%$ survival and the normal ones, dropped in the autumn to $6.5 \%$ (Table 3 ).

The difference in average percentages of empty cells between colonies of $100 \%$ and $50 \%$ survival groups was also much lower in autumn than in summer. This means, that queens producing brood of $50 \%$ survival laid eggs earlier in cells from which larvae were eaten, in period when the brood area was small, as compared to the time when it was large. 


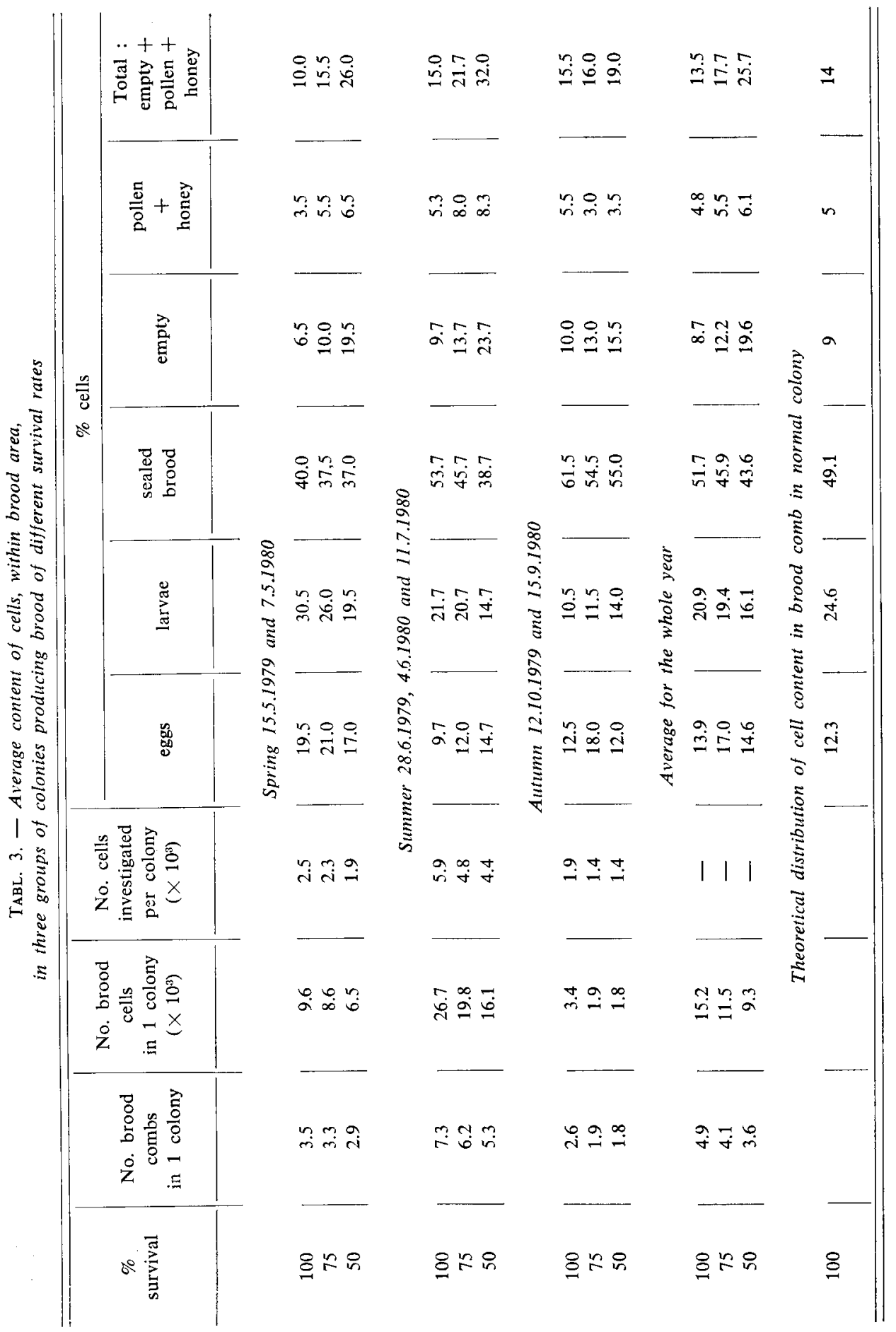



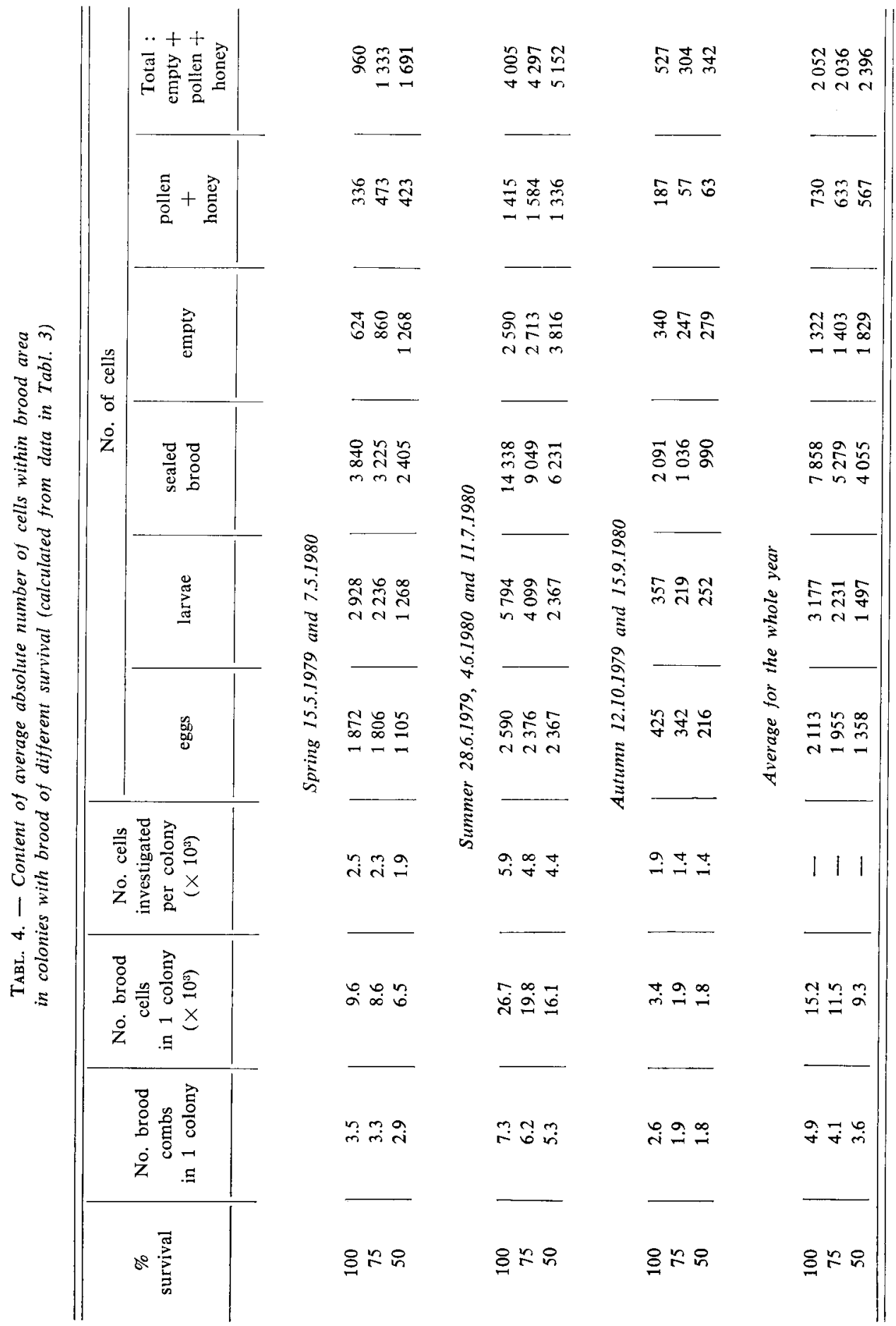
2. Average exploitation of comb cells for brood rearing during the active season

Averages for the whole year are presented in Table 3 and show, that fewer brood combs were present in colonies with brood of lower survival rate than in the normal ones. But 0,7\%-3,1\% more cells contained eggs in colonies with brood of decreased survival rate than in the normal ones. Larvae occupied $5 \%$ fewer cells and $10 \%$ fewer sealed brood in colonies of the $50 \%$ survival group than in the normal ones. On average, $9 \%, 12 \%$ and $20 \%$ of empty cells were found in colonies of the $100 \%, 75 \%$ and $50 \%$ survival groups. Higher percentages of cells appear to be filled with pollen and honey in colonies with brood of lower survival rates than in the normal ones.

\section{Comparison of theoretical contents of cells within brood area with the actual one found in different conditions}

Table 3 shows, that about $9 \%$ of cells within the brood area in normal colonies were empty and about $5 \%$ were filled by pollen and honey. Thus, about $14 \%$ of cells within the brood area were not used for brood rearing in normal colonies during the active season. The remaining $86 \%$ of cells were occupied by brood in different developmental stages. Since the eggs, unsealed brood and larvae develop in 3, 6 and 12 days, respectively, so $12,3 \%, 24,6 \%$ and $49,1 \%$ of cells should be occupied by brood in three developmental stages.

Table 3 shows that in the spring the eggs in all three groups and larvae in two groups filled more cells than in theory. This indicates rapid growth of the colony caused by significant increase of brood rearing activity.

In summer the fraction of cells occupied by eggs and larvae in normal colonies is lower and that of sealed brood higher than in the theoretical distribution. This indicates restriction of the queen in egg laying activity possibly due to heavy nectar influx to the colony. Higher percentage of eggs and lower percentage of larvae were found in summer in colonies with brood of $50 \%$ survival. This indicates that the workers eat some larvae and the queen again lays eggs into the emptied cells.

In all three groups of colonies in autumn, the eggs occupied similar percentages of cells, the larvae lower and sealed brood higher percentages than in theoretical distribution. This shows, that the workers eat part of the larvae in autumn in all three groups of colonies. The higher percentage of sealed brood may be explained as remnants of the previously larger amount of brood reared. 


\section{Absolute numbers of different brood stages}

Since numbers of cells within brood area are known, as well as the percentage of cells occupied by different brood developmental stages, absolute numbers of those stages present in the colonies may be calculated (Table 4).

In the spring, queens producing brood of $50 \%$ survival rate laid fewer eggs than those producing brood of higher survival. This was probably due to low population of colonies with brood of $50 \%$ survival. Queens of the $75 \%$ survival group produced almost the same number of eggs as normal queens.

In the summer, queens of all three survival groups laid similar numbers of eggs. Queens of the $50 \%$ survival group produced in particular periods even more eggs than the normal ones. For instance, 3552 and 3894 eggs were found in early summer in colonies of the $100 \%$ and $50 \%$ survival groups, respectively (Table 2), and 215 and 1404 eggs in mid summer, respectively (Table 1). This was probably caused by the lack of empty cells in normal colonies due to heavy nectar flow, and there was always a surplus of empty cells in colonies with brood of $50 \%$ survival rate.

In autumn, queens of both groups producing brood of decreased survival laid fewer eggs than the normal ones. The relation differed in particular years, for example, 224 eggs were found in the autumn of 1980, in colonies producing brood of $50 \%$ survival and 180 only, in the normal ones.

In spring and autumn the numbers of empty cells found in colonies with brood of $50 \%$ survival were similar to the numbers of eggs found there.

Table 4 shows, that queens producing brood of $50 \%$ survival laid on average for the whole year fewer eggs, and those producing brood of $75 \%$ survival laid a similar number to that produced by normal queens.

Even in periods when queen producing brood of $50 \%$ survival laid similar or higher numbers of eggs than normal queens, the first laid many eggs not into new cells but into those from which diploid drone larvae had been eaten. This caused the percentage of empty cells in colonies with brood of lower survival rate to be lower than the percentage of larvae eaten. As a result, the total number of cells used for brood rearing, as well as the brood area in colonies with low brood survival rate was lower than in normal colonies. Thus, when queens producing brood of lower survival rate they laid more eggs than the normal ones, the total production of worker bees was lower and the colonies were weaker than the normal ones. 


\title{
DISCUSSIONS AND CONCLUSIONS
}

The interaction found in this study between the progress of the season and exploitation of comb cells within brood area in the three groups of colonies producing brood of different survival rates was similar to that, occuring between progress of the season and brood area or colony population (WOYKE, 1980, 1981). A high percentage of larvae being eaten by workers in normal colonies in the autumn, confirm earlier findings concerning $A$. mellifera (WoYKE, 1977) as well as those obtained in unfavorable conditions for $A$. cerana (Woyke, 1976).

On average, queens producing brood of $50 \%$ survival laid fewer eggs than the normal ones, but some times the queens laid in summer more eggs than the normal ones. The percentage of empty cells within brood area was higher in colonies with brood of decreased survival than in the normal ones. Differences among the three groups increased in late summer during maximal brood production. Nevertheless, percentage of cells not used for brood rearing within the brood area, was always lower in colonies producing larvae of lower survival rate than the percentage of diploid drone larvae being eaten by workers. This indicates, that queens producing brood of decreased survival rate lay eggs into empty cells shortly after the larvae were eaten.

Received for publication in April 1984.

\author{
RESUME \\ UTHLISATION DES CELLULES POUR L'ÉLEVAGE DU COUVAIN \\ DANS DES COLONIES D'ABEILLES PRODUISANT DES LARVES \\ AVEC DIVERS TAUX DE SURVIE
}

\footnotetext{
Des reines vierges ont été inséminées artificiellement avec du sperme de 2 de leurs frères et ont été réparties en 3 groupes selon le taux de survie du couvain produit : survie à $100 \%$ (groupe I), survie à $75 \%$ (groupe II) et survie à $50 \%$ (groupe III). On a étudié le contenu des cellules situées dans $1 \mathrm{dm}^{2}$ au centre du nid à couvain sur chacune des faces des rayons à couvain. Trois colonies de chaque groupe ont été étudiées au printemps, en été et à l'automne, sur 2 années. Au total on a déterminé le contenu de 210780 cellules.

Les cellules du nid à couvain des colonies normales renferment en moyenne $14 \%$ d'œufs, $21 \%$ de larves, $51 \%$ de couvain operculé, $9 \%$ de cellules vides et $5 \%$ de cellules remplies de pollen et de miel. Les proportions varient en fonction de la saison et du taux de survie du couvain.

Au printemps les cellules renferment respectivement $20 \%, 21 \%$ et $17 \%$ d'œufs dans les colonies des groupes I, II et III, et durant l'été $10 \%, 12 \%$ et $15 \%$ respectivement. En été plus le taux de survie baisse, plus le pourcentage de cellules renfermant des oufs augmente et la fraction de cellules contenant des larves est plus faible que dans des colonies normales. En automne on a trouvé des pourcentages similaires dans les 3 groupes. Ceci indique qu'un fort pourcentage de larves est mangé à la fin de la saison par les ouvrières des colonies normales.
} 
On a trouvé des cellules vides dans $5 \%, 10 \%$ et $20 \%$ des cas dans les groupes I, II et III respectivement, au printemps et $10 \%, 15 \%$ et $25 \%$ en été. Si l'on ajoute les cellules remplies de pollen et de miel, c'est $15 \%, 20 \%$ et $30 \%$ des cellules qui ne sont pas utilisées pours l'élevage du couvain en été. Le taux des cellules non utilisées pour l'élevage du couvain est plus faible dans les colonies, dont les larves ont un taux de survie réduit, que le pourcentage de larves mâles diplö̈des mangées par les ouvrières. Ceci indique que les reines n'attendent pas pour pondre que toutes les abeilles soient écloses du rayon, mais qu'elles déposent de nouveaux œufs dans des cellules vides peu de temps après que les larves mâles diplö̈des sont mangées.

Les reines qui produisent dụ couvain à $50 \%$ de survie déposent plus d'œufs que celles qui produisent du couvain à $75 \%$ et $100 \%$ de survie au début et au milieu de l'été. Aux autres saisons elles en pondent moins. Il y a toujours moins de couvain operculé que dans les colonies normales. Il en résulte que les colonies qui ont du couvain à faible taux de survie sont moins populeuses que les colonies normales. Cela réduit le nombre d'œufs pondus au printemps et à l'automne par les reines qui produisent du couvain à taux de survie réduit.

\section{ZUSAMMENFASSUNG}

\section{AUSNUTZUNG DER WABENZELLEN IM BRUTNEST VON BIENENVÖLKERN MIT MADEN UNTERSCHIEDLICHER ÜBERLEBENSRATEN}

Genetisch definierte Königinnen wurden instrumentell mit Sperma zweier ihrer Brüder besamt. So enstanden 3 Gruppen von Königinnen, die Brut mit einer Überlebensrate von $100 \%, 75 \%$ und $50 \%$ erzeugten. Der Inhalt von 210780 Wabenzellen innerhalb des Brutbezirks wurde über 2 Jahre in 5 Bienenvölkern untersucht.

Durchschnittlich waren bei normalen Völkern innerhalb des Brutnestes Zellen mit folgendem Inhalt $\mathrm{zu}$ finden : Eier $14 \%$, Maden $21 \%$, verdeckelte Brut $51 \%$, Honig und Pollen $5 \%$, Leerzellen $9 \%$.

Im Sommer gab es einen höheren Anteil von Eizellen bei Völkern mit Brut geringerer Überlebensraten und einen geringeren Anteil von Madenzellen. Im Herbst wurden ähnliche Anteile von Ei- und Madenzelle in allen drei Gruppen von Völkern gefunden. Dieser Befund deutet darauf hin, daß zu dieser Jahreszeit in normalen Völkern ein hoher Prozentsatz von Maden von den Bienen gefressen wird.

Während des Sommers wurden folgende Verhältnisse zwischen der Anzahl der nicht für Brutaufzucht genutzten Zellen und der Überlebensrate der Brut gefunden : Leerzellen $15 \%$ bei $100 \%$ Ubberlebensrate, $20 \%$ bei $75 \%$ und $30 \%$ bei $50 \%$. Dieser Befund zeigt, daß die Königin die Zellen nach dem Fressen der diploiden Drohnenmaden zur Eilage benutzt und nicht mit der Bestiftung wartet, bis die Brutentwicklung beendet ist. Bei reduzierter Überlebensrate der Brut war weniger verdeckelte Brut vorhanden. Daher wiesen solche Völker eine geringere Stärke auf als normale.

\section{REFERENCES}

Mackensen O., 1951. - Viability and sex determination in the honey bee. J. Hered., 46, 72-74.

Page R.E. and Laidlaw H.H., 1982. - Closed population honeybee breeding. 1. Population genetics of sex determination. J. apic. Res., 19, 30-17.

Woyke J., 1963 a. - Drone larvae from fertilized eggs of the honeybee. J. apic. Res., 2, 19-24. 
Woyke J., 1963 b. - What happens to diploid drone larvae in a honeybee colony. J. apic. Res., 2 , 73-76.

Woyke J., 1976. - Brood-rearing efficiency and absconding in Indian honeybees. J. apic. Res., 15, 133-143.

WOYKe J., 1977. - Cannibalism and brood-rearing efficiency in the honeybee. J. apic. Res., 16, 84-94.

Woyke J., 1980. - Effect of sex allele homo-heterozygosity on honeybee colony population and on their honey production. 1. Favorable development conditions. J. apic. Res., 19, 51-63.

Woyke J., 1981. - Effect of sex allele homo-heterozygosity on honeybee colony population and on their honey production. 2. Unfavorable development conditions and restricted queens. J. apic. Res., 20, 148-155. 